Provided for non-commercial research and education use. Not for reproduction, distribution or commercial use.

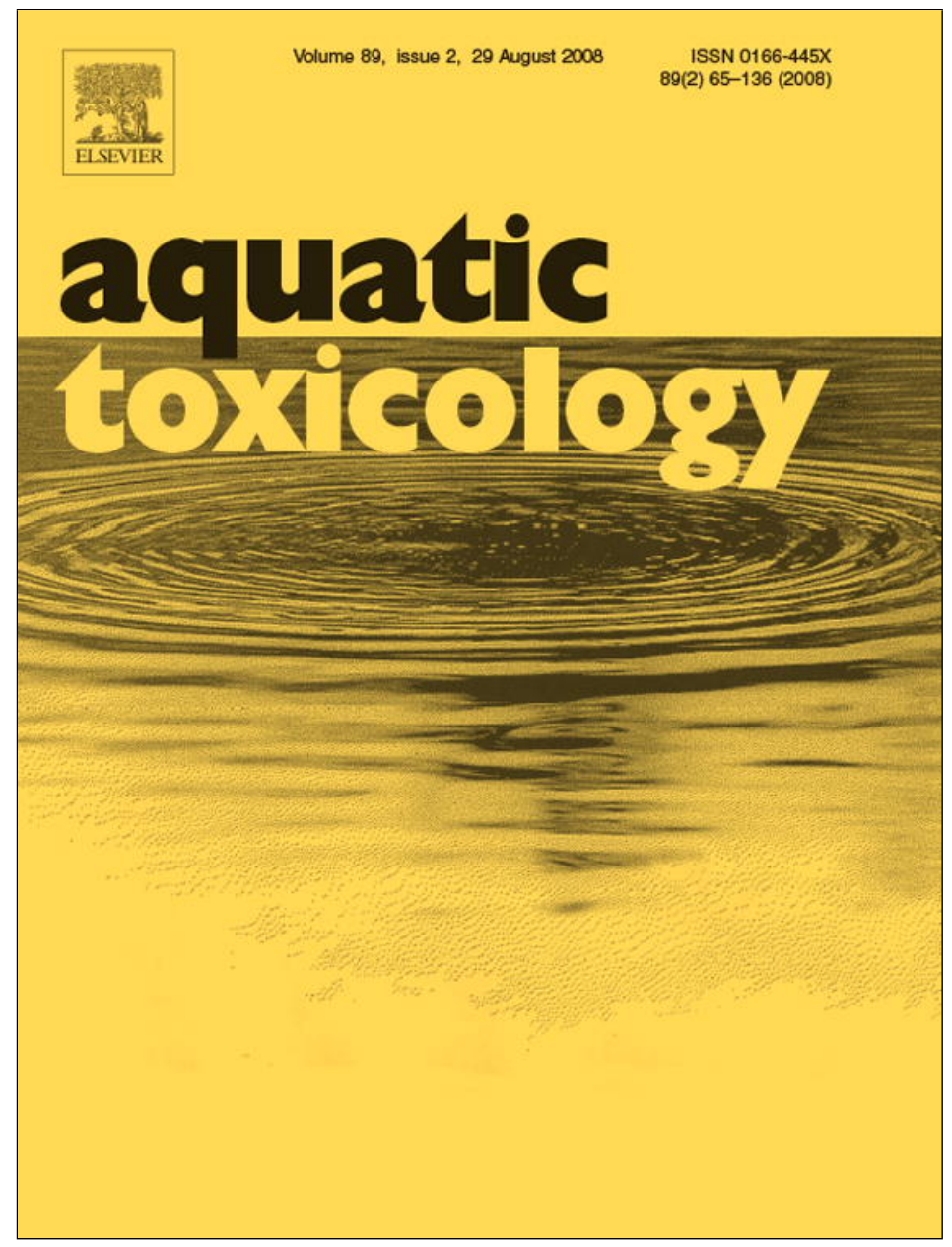

This article appeared in a journal published by Elsevier. The attached copy is furnished to the author for internal non-commercial research and education use, including for instruction at the authors institution and sharing with colleagues.

Other uses, including reproduction and distribution, or selling or licensing copies, or posting to personal, institutional or third party websites are prohibited.

In most cases authors are permitted to post their version of the article (e.g. in Word or Tex form) to their personal website or institutional repository. Authors requiring further information regarding Elsevier's archiving and manuscript policies are encouraged to visit:

http://www.elsevier.com/copyright 


\title{
Iron and radical content in Mya arenaria Possible sources of NO generation
}

\author{
Paula Mariela González ${ }^{a}$, Doris Abele ${ }^{b}$, Susana Puntarulo ${ }^{a, *}$ \\ a Physical Chemistry-PRALIB, School of Pharmacy and Biochemistry, University of Buenos Aires, Junin 956, 1113 Buenos Aires, Argentina \\ ${ }^{\mathrm{b}}$ Alfred Wegener Institute for Polar and Marine Research, Department of Shelf Sea Ecology, Am Handelshafen 12, 27570 Bremerhaven, Germany
}

\section{A R T I C L E I N F O}

\section{Article history:}

Received 10 April 2008

Received in revised form 9 June 2008

Accepted 10 June 2008

\section{Keywords:}

Mya arenaria

Lipid radicals

Ascorbyl radical

Nitric oxide

Iron

\begin{abstract}
A B S T R A C T
The objective of this work was to analyze oxidative metabolism in Mya arenaria. Total Fe content in $M$. arenaria collected in the German Wadden Sea was $1.9 \pm 0.7,0.7 \pm 0.1$ and $0.17 \pm 0.01 \mathrm{nmol} / \mathrm{mg}$ fresh weight (FW), in digestive glands (DG), mantle and gills, respectively. Labile Fe pool, assessed by electronic paramagnetic resonance (EPR), was $146 \pm 10 \mathrm{pmol} / \mathrm{mg} \mathrm{FW}$, and by the fluorescence method employing calcein it was $118 \pm 9 \mathrm{pmol} / \mathrm{mg}$ FW. The lipid radical content in the DG, assessed by EPR, was $27 \pm 7 \mathrm{pmol} / \mathrm{mg} \mathrm{FW}$, and the thiobarbituric reactive substances content amounted to $57 \pm 8 \mathrm{pmol} / \mathrm{mg} \mathrm{FW}$. Ascorbyl radical $\left(\mathrm{A}^{\bullet}\right)$ content, assessed by quantification of EPR signals, was $0.04 \pm 0.01 \mathrm{pmol} / \mathrm{mg} \mathrm{FW}$, and the ascorbate content $\left(\mathrm{AH}^{-}\right)$was $478 \pm 12 \mathrm{pmol} / \mathrm{mg} \mathrm{FW}$. The ratio $\mathrm{A}^{\bullet} / \mathrm{AH}^{-}$was $(8 \pm 1) \times 10^{-5} \mathrm{AU}$, suggesting a minimum oxidative stress even under physiological conditions, presumably depending on basal metabolic functions. The content of nitric oxide (NO), assessed by EPR, was $99 \pm 3 \mathrm{pmol} / \mathrm{mg}$ FW. The generation rate of NO by nitric oxide synthase-like activity (NOS-like) was assayed as NO production detected by EPR in the presence of L-arginine and NADPH, and was $3.16 \pm 0.06 \mathrm{pmol} /(\mathrm{mg} \mathrm{FW} \mathrm{min})$. The data presented here document the detectable presence of highly reactive species in M. arenaria.
\end{abstract}

(c) 2008 Elsevier B.V. All rights reserved.

\section{Introduction}

Live cells continuously produce low amounts of reactive species like superoxide anion and hydrogen peroxide as by-products of aerobic metabolism. The hydrogen peroxide is further involved with transition metals through the Fenton reaction forming highly reactive hydroxyl radicals (Puntarulo and Cederbaum, 1988). Moreover, some cellular constituents like ascorbate $\left(\mathrm{AH}^{-}\right)$can reduce oxidized $\mathrm{Fe}^{3+}$ to $\mathrm{Fe}^{2+}$ generating catalytically active Fe that fuels hydroxyl radical and ascorbyl radical $\left(\mathrm{A}^{\bullet}\right)$ formation. Also, unsaturated membrane lipids can generate radical species like peroxyl $\left(\mathrm{ROO}^{\bullet}\right)$, alkoxyl $\left(\mathrm{RO}^{\bullet}\right)$ and alkyl $\left(\mathrm{R}^{\bullet}\right)$ radicals by reactions catalyzed by Fe. Finally, besides being a cellular signalling molecule capable of binding Fe with an stability constant $\left(K_{\mathrm{Fe}^{2+}-\text { citrate:NO}}\right)$ of $2.1 \times 10^{4} \mathrm{M}^{-1}$ (Schneppensieper et al., 2001), nitric oxide (NO) is a regularly occurring radical intermediate of many reactions. NO has been shown to act as intracellular or transcellular signal and as cytotoxic host defense compound (Moncada et al., 1991; Knowles and Moncada, 1994; Moncada and Higgs, 1995). NO is gen-

\footnotetext{
* Corresponding author at: Fisicoquímica, Facultad de Farmacia y Bioquímica, Junín 956, Buenos Aires C1113AAD, Argentina. Tel.: +54 114964 8244x101; fax: +541145083646 x 102 .

E-mail address: susanap@ffyb.uba.ar (S. Puntarulo).
}

erated in mammal cells and tissues from L-arginine (L-A) by the activity of the enzyme nitric oxide synthase (NOS, EC1.14.13.39) (Knowles, 1997). NOS-like enzyme activity has been detected in marine, freshwater and terrestrial molluscs, including three gastropod subclasses (prosobranchs, opisthobranchs and pulmonates) (Jacklet, 1997). Johansson and Carlberg (1995) and Moroz and Gillette (1995) summarized data on NOS-like activity detected by NADPH-diaphorase histochemistry in the central nervous system of mollusc species. Stefano and Ottaviani (2002) reported that some invertebrate organisms also contain NO, and Tafalla et al. (2003) demonstrated that clam hemocytes are capable of producing NO in response to zymozan, lipopolysaccharide or pathogenic bacteria. The gene coding for enzymes generating NO, presumably analogues of NO synthases, was reported in several invertebrates (Regulski and Tully, 1995; Luckhart et al., 1998; Nighorn et al., 1998; Imamura et al., 2002). Basically, pro- and anti-oxidant processes are the same in marine invertebrates and in mammalian systems (Livingstone et al., 1990; Livingstone, 1991; Winston and Di Giulio, 1991). However, the specific conditions for radical formation, a key feature in stress physiology and aging, are different and highly variable among species in aquatic cold blooded organisms (Lesser, 2006) where metabolic rates are much lower than in mammals (Abele and Puntarulo, 2004).

The soft shell clam Mya arenaria from the European Wadden Sea is a typical representative of the group of infaunal marine molluscs. 
It is a benthic filter feeder that colonizes intertidal and subtidal areas where it digs $50 \mathrm{~cm}$ deep into the sediment. $M$. arenaria takes up $\mathrm{O}_{2}$ and food particles (algae and detritus) from surface waters through a long siphon, and is exposed to hypoxia-reoxygenation as tidal flats emerge and are again flooded. As particle feeding is not totally selective, $M$. arenaria ingests considerable amounts of sediment containing Fe and other trace metals together with the targeted food particles. These elements are taken up into the tissues. The amount of trace elements absorbed into the tissues from digestion of ingested food particles largely depends on the amounts available in the environment (Estévez et al., 2002). As the Wadden Sea receives nutrients and trace metals from river discharge and land run-off processes, dissolved and particulate matter can depend on many factors, including precipitation, and be variable in space and time. Fe discharge at five representative locations of the German Wadden Sea coast recorded values between 2 and $50 \mu \mathrm{mol}$ $\mathrm{Fe}_{\text {diss }} / \mathrm{l}$ and between 13 and $80 \mu \mathrm{mol} \mathrm{Fe}$ part $/ \mathrm{l}$ (Kölsch et al., 2003). The average $\mathrm{Fe}_{2} \mathrm{O}_{3}$ content amounted to $0.8 \%$ in sand flats, $1.8 \%$ in mixed and $3.2 \%$ in mud flats. The sand flat where the animals for this study were collected had $7.5 \mathrm{mg} \mathrm{Fe} / \mathrm{g}$ dry weight (DW) (Estévez et al., 2002).

In most animal tissues Fe is tightly bound to Fe-specific binding proteins such as ferritin $(\mathrm{Ft})$ and it is not available for biochemical reactions. However, to a certain extent tissues also contain a labile Fe pool (LIP) which represents the catalytically active Fe. This fraction is defined as a low-molecular-weight pool of weakly chelated Fe that rapidly moves through the cell. It likely consists of both forms of ionic $\mathrm{Fe}$ (ferrous, $\mathrm{Fe}^{2+}$ and ferric, $\mathrm{Fe}^{3+}$ ) associated with a variety of ligands with low affinity for Fe ions such as, citrate and other organic ions, phosphate, carbohydrates and carboxylates, nucleotides and nucleosides, polypeptides and phospholipids (Kakhlon and Cabantchik, 2002; Petrat et al., 2002; Kruszewski, 2003), but also mildly bound Fe to proteins could be included in this pool (Petrák and Vyoral, 2001). LIP represents only a minor fraction of total cellular Fe (3-5\%) (Kruszewski, 2004). However, the actual nature of the intracellular ligands participating in LIP formation remains obscure up to now. The accessibility of cellular Fe to chelators (such as deferoxamine, DF) is commonly used as the criterion of 'lability'.

In this work we measured both, total Fe and LIP in digestive gland (DG) homogenates of the bivalve $M$. arenaria. Oxidative condition arising from $\mathrm{Fe}$ in both the lipid and hydrophilic fraction of the tissue, was assessed by measuring lipid peroxidation and the $\mathrm{A}^{\bullet} / \mathrm{AH}^{-}$ratio, respectively. The presence of the Fe ligand NO in DG tissue, and the rate of NO formation were estimated in this bivalve species to characterize basal oxidative and nitrosative stress under controlled environmental conditions.

\section{Materials and methods}

\subsection{Animal collection and maintenance}

Bivalves of the species $M$. arenaria L. (5.3-8.8 cm shell length and $3.2-5.1 \mathrm{~cm}$ shell width) were collected on an intertidal sand flat near Bremerhaven, Germany, over the summer 2006-2007 (June-July). In the laboratory, animals were kept in two aquaria with fully aerated natural seawater of $23-26 \%$ PSU and at $10^{\circ} \mathrm{C}$ for 1 week to ensure constant and control conditions prior to the experiments. The bottom of the aquaria was covered with pebble stones. Animals were fed live phytoplankton twice a week, using DT's live marine phytoplankton, premium reef blend (Nannochloropsis oculata, Phaeodactylum sp., Tricornotum sp., Chlorella sp., between 2 and $20 \mu \mathrm{m})$. The tissues were dissected and stored in liquid nitrogen until used.

\subsection{Total Fe content}

Approximately $100 \mathrm{mg}$ of DG, mantle and gills were weighed and dried to constant weight at $70^{\circ} \mathrm{C}$ over $48 \mathrm{~h}$, before digesting with $\mathrm{HClO}_{4}: \mathrm{HNO}_{3}(1: 1)$ solution. Concentrations of $\mathrm{Fe}$ in the extracts were measured spectrophotometrically at $535 \mathrm{~nm}$ after reduction with thioglycolic acid (TGA), and the addition of bathophenanthroline (4,7-diphenyl-1,10-phenanthrolinedisulfonic acid) (Brumby and Massey, 1967).

\subsection{2-Thiobarbituric acid reactive substances (TBARS) content}

TBARS content in DG homogenates was measured according to Uchiyama and Mihara (1978), as described in Storch et al. (2001), and Abele et al. (2002). Absolute malondialdehyde (MDA) concentrations were calculated as described in Abele et al. (2002).

\subsection{Content of lipid radical assessed by electron paramagnetic resonance (EPR)-spin trapping}

The homogenates of DG were prepared in potassium phosphate buffer ( $\mathrm{pH} 7.4$ ) containing $100 \mu \mathrm{M}$ DF and $130 \mathrm{mM}$ of the spin trap $\alpha$-(4-pyridyl 1 -oxide)- $N$ - $t$-butyl nitrone (POBN). The samples were incubated for $10 \mathrm{~min}$ at $10^{\circ} \mathrm{C}$ before measuring. EPR spectra were measured using a Bruker (Karlsruhe, Germany) spectrometer ECS 106 with a cavity ER 4102ST, operating with the following instrument settings: room temperature $\left(18^{\circ} \mathrm{C}\right), 9.81 \mathrm{GHz}$ microwave frequency, $20 \mathrm{~mW}$ microwave power, $50 \mathrm{kHz}$ modulation frequency, $1.232 \mathrm{G}$ modulation amplitude, $81.92 \mathrm{~ms}$ time constant and $2 \times 10^{4}$ receiver gain (Jurkiewicz and Buettner, 1994). Quantification was performed according to Kotake et al. (1996).

\section{5. $A^{\bullet}$ content}

Measurements were performed at room temperature $\left(18^{\circ} \mathrm{C}\right)$ in the EPR spectrometer described above. Homogenates from DG were prepared in $1 \mathrm{mM}$ DF in pure dimethylsulfoxide (DMSO) (1:4) and immediately transferred to a Pasteur pipette for $\mathrm{A}^{\bullet}$ detection. Instrument settings were as follows: $9.76 \mathrm{GHz}$ microwave frequency, $10 \mathrm{~mW}$ microwave power, $50 \mathrm{kHz}$ modulation frequency, $1 \mathrm{G}$ modulation amplitude, $3487 \mathrm{G}$ centered field, $327.68 \mathrm{~ms}$ time constant, $81.92 \mathrm{~ms}$ conversion time, $1 \times 10^{5}$ receiver gain and $15 \mathrm{G}$ sweep width. Quantification of the spin adduct was performed using an aqueous solution of 4-hydroxy-2,2,6,6tetramethylpiperidinyloxy (TEMPOL) introduced into the same sample cell used for the samples. EPR spectra for both sample and TEMPOL solutions were recorded at exactly the same spectrometer settings and the first derivative EPR spectra were double integrated to obtain the area intensity, from which the concentration of the radical was calculated according to Kotake et al. (1996).

\section{6. $A H^{-}$content}

The content of $\mathrm{AH}^{-}$was measured by reverse phase HPLC with electrochemical detection. DG samples were homogenized in metaphosphoric acid 10\% (w/v) according to Kutnink et al. (1987). Commercially available $\mathrm{AH}^{-}$was used as standard.

\subsection{LIP in DG}

The LIP was determined by both EPR at $77 \mathrm{~K}$, according to Woodmansee and Imlay (2002), and by a fluorescence technique with the Fe sensor calcein (CA) according to Darbari et al. (2003) with modifications. For the EPR measurements, DG tissue samples were homogenized in $10 \mathrm{mM}$ Tris- $\mathrm{HCl}$ buffer, $120 \mathrm{mM}$ 
$\mathrm{KCl} \mathrm{pH} 7.4$ and $1 \mathrm{mM}$ DF. The measurements were performed using the following instrument settings: $9.75 \mathrm{GHz}$ microwave frequency, microwave power $20 \mathrm{~mW}, 50 \mathrm{kHz}$ modulation frequency, $4.759 \mathrm{G}$ modulation amplitude, centered field $1600 \mathrm{G}$, time constant $81.92 \mathrm{~ms}$, and $800 \mathrm{G}$ sweep width. For the fluorescence technique, DG were homogenized in $40 \mathrm{mM}$ potassium phosphate buffer, $120 \mathrm{mM} \mathrm{KCl}$, pH 7.4 in 1:10 proportion. The homogenate was centrifuged at $8700 \times \mathrm{g}$ for $15 \mathrm{~min}$ at $4{ }^{\circ} \mathrm{C}$ and the supernatant removed to fresh Eppendorf tubes and centrifuged again at $8700 \times \mathrm{g}$ for $15 \mathrm{~min}$ at $4{ }^{\circ} \mathrm{C}$. The supernatant was filtered through filters with 30,000 nominal molecular weight limit (Centricon YM30). The filtered solution was then reduced with equal volume of $8 \%$ TGA. Fe in the reduced solution was measured using $1 \mu \mathrm{M}$ CA solution in $40 \mathrm{mM}$ potassium phosphate buffer, $120 \mathrm{mM} \mathrm{KCl}, \mathrm{pH}$ 7.4. When $\mathrm{Fe}$ is added to CA solution a fraction of the dye binds free $\mathrm{Fe}^{2+}$ leading to the generation of the Fe-bound (quenched) complex [CA-Fe], while another fraction remains free as unbound CA and provides the residual fluorescence. The fluorescence $\left(\lambda_{\operatorname{exc}}=485 \mathrm{~nm}\right.$, $\lambda_{\text {em }}=535 \mathrm{~nm}$ ) was recorded until stabilization of the signal $\left(F_{1}\right)$ and then DF was added to a final concentration of $1 \mathrm{mM}$. The fluorescence was monitored until a new stabilization of the signal $\left(F_{2}\right)$. The magnitude of the absolute change in fluorescence $\left(F_{2}-F_{1}\right)$ is equivalent to the amount of $\mathrm{Fe}$ bound to $\mathrm{CA}$. The fractional increase of fluorescence $(\Delta F)$, that reflects the LIP concentration, was calculated using the following equation:

$\Delta F=\frac{F_{2}-F_{1}}{F_{2}}$

The LIP was assessed according to Robello et al. (2007) using Eq. (2) and a dissociation constant $\left(K_{\mathrm{d}}\right)$ value of $0.46 \mu \mathrm{M}$.

$\mathrm{LIP}=(\Delta F \times[\mathrm{CA}])+\left[\frac{K_{\mathrm{d}} \mathrm{x} \Delta F}{1-\Delta F}\right]$

\subsection{NO content}

The NO content was determined both by measuring total nitrite and nitrate concentration following Griess reaction, according to Verdon et al. (1995) with modifications, and by EPR. For the Griess reaction, DG were homogenized in $14 \mathrm{mM}$ sodium phosphate buffer $(\mathrm{pH} 7.1)$, in a 1:1.5 ratio. Nitrate in the extracts was reduced to nitrite, then the sample was incubated for $10 \mathrm{~min}$ with the Griess reagent. The concentration of nitrate plus nitrite was measured spectrophotometrically at $540 \mathrm{~nm}$. Quantification was performed using a nitrate and nitrite standard curve.

For the EPR measurements DG were homogenized in $60 \mathrm{mM}$ Tris- $\mathrm{HCl}$ buffer- $100 \mathrm{mM} \mathrm{KCl} \mathrm{pH} \mathrm{7.0,} \mathrm{in} \mathrm{a} \mathrm{1:0.7} \mathrm{ratio,} \mathrm{supplemented}$ with the spin trap solution ( $10 \mathrm{mM}$ sodium- $\mathrm{N}$-methyl-D-glucamine dithiocarbamate (MGD), $1 \mathrm{mM} \mathrm{FeSO}_{4}$ ). The supernatant was immediately transferred to Pasteur pipettes for EPR measurements. The spectra were recorded at room temperature $\left(18^{\circ} \mathrm{C}\right)$ in the EPR spectrometer described above, operating at $9.76 \mathrm{GHz}$ microwave frequency, $20 \mathrm{~mW}$ microwave power, $50 \mathrm{kHz}$ modulation frequency, $5.983 \mathrm{G}$ modulation amplitude, $200 \mathrm{G}$ field scan, $327.68 \mathrm{~ms}$ time constant, 83.886s sweep time. Quantification of the spin adduct was performed using an aqueous solution of TEMPOL as described above.

\subsection{NO generation by NOS-like activity}

DG were homogenized with $60 \mathrm{mM}$ Tris-HCl buffer- $100 \mathrm{mM} \mathrm{KCl}$ $\mathrm{pH} 7.0$, in a 1:0.7 ratio, in the presence of the spin trap solution (10 mM MGD, $1 \mathrm{mM} \mathrm{FeSO}_{4}$ ). To assess NOS-like dependent NO generation, the homogenate was supplemented with $0.1 \mathrm{mM} \mathrm{NADPH}$, $5 \mathrm{mM} \mathrm{MgCl}_{2}, 1 \mathrm{mM} \mathrm{CaCl} 2$ and $1 \mathrm{mM} \mathrm{L}$-arginine (L-A). In the inhibition experiments with $\mathrm{L}-\mathrm{A}$ analogs, such as $\mathrm{N} \omega$-nitro-L-arginine methyl ester hydrochloride (L-NAME) and N $\omega$-nitro-L-arginine ( $\mathrm{L}-$ $\mathrm{NA}$ ), final concentrations used were $5 \mathrm{mM}$. The homogenate was pre-incubated $5 \mathrm{~min}$ with the inhibitors at $18^{\circ} \mathrm{C}$ before the addition of NADPH and L-A. The NO EPR spectra were recorded as a function of time, at room temperature $\left(18^{\circ} \mathrm{C}\right)$ employing the instrument settings described above. The cursor was fixed at $3411 \mathrm{G}$. The increasing height of the peak was recorded during $24 \mathrm{~min}$ to assess the rate of generation of NO.

\subsection{Statistical analyses}

Data in the text and tables are expressed as mean \pm S.E. of six independent experiments $(n=6)$, with two replicates for each sample. Statistical tests were carried out using Statview for Windows, ANOVA, SAS Institute Inc., version 5.0.

\section{Results}

Total Fe content in M. arenaria collected in the German Wadden Sea for this study, was $1.9 \pm 0.7,0.7 \pm 0.1$ and $0.17 \pm 0.01 \mathrm{nmol} / \mathrm{mg}$ fresh weight (FW), in DG, mantle and gills, respectively. EPR assessment of LIP by the signal of the DF- $\mathrm{Fe}^{3+}$ complex is understood as a reliable method for detection (Tarpey et al., 2004), but the fluorescence method employing CA seems to be even more sensitive (Espósito et al., 2002). The LIP was measured by both methods to confirm the accuracy of the data. The typical EPR signal of DF- $\mathrm{Fe}^{3+}$ complex was obtained with DG, in agreement with the signal detected in the presence of $15 \mu \mathrm{M} \mathrm{FeCl}$ (Fig. 1). LIP assessed by the CA assay ( $118 \pm 9 \mathrm{pmol} / \mathrm{mg} \mathrm{FW})$, was not significantly different from the value obtained using the EPR technique $(146 \pm 10 \mathrm{pmol} / \mathrm{mg} \mathrm{FW})$.Since lipid peroxidation in the tissues may correlate with elevated accumulation of catalytically active $\mathrm{Fe}$, it was estimated in the DG of $M$. arenaria, both as the content of lipid radicals assessed by EPR, and as the content of TBARS. Lipid radicals combined with the spin trap POBN resulted in adducts that gave a characteristic EPR spectrum with hyperfine coupling constants of $a^{\mathrm{N}}=15.8 \mathrm{G}$ and $a^{\mathrm{H}}=2.6 \mathrm{G}$, in agreement with computer simulated signals obtained using those parameters (Fig. 2). Even though these constants could be assigned to lipid radicals (Buettner, 1987), spin trapping studies cannot readily distinguish between $\mathrm{ROO}^{\bullet}, \mathrm{RO}^{\bullet}$ and $\mathrm{R}^{\bullet}$ adducts, owing to the similarity of the corresponding coupling constants (Buettner, 1987). POBN itself was examined and no POBN spin adducts were observed (Fig. 2). Lipid radical content in the DG of M. arenaria was $27 \pm 7 \mathrm{pmol} / \mathrm{mg}$ FW. TBARS, a widely accepted index for lipid per-

(a)

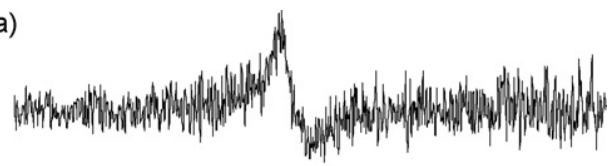

(b)

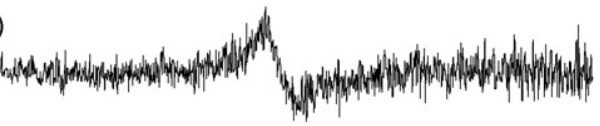

(c)

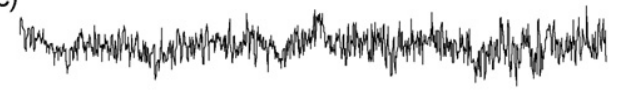

$50 \mathrm{G}$

Fig. 1. Determination of LIP by EPR. Spectra from: (a) $15 \mu \mathrm{M}$ standard Fe, (b) DG from M. arenaria, and (c) $10 \mathrm{mM}$ Tris- $\mathrm{HCl}$ buffer, $120 \mathrm{mM} \mathrm{KCl} \mathrm{pH} 7.4$ and $1 \mathrm{mM} \mathrm{DF}$. 

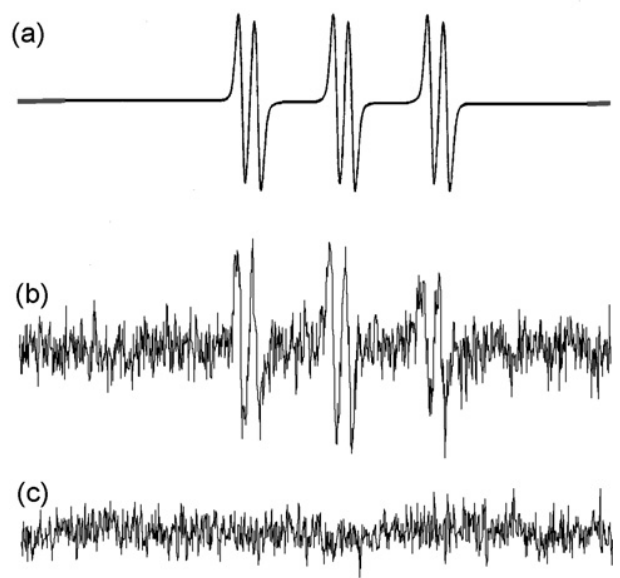

$20 \mathrm{G}$

Fig. 2. Lipid radical detection by EPR. Spectra from: (a) computer-simulated exhibiting hyperfine splittings that are characteristic of POBN/lipid radicals, $a^{\mathrm{N}}=15.56 \mathrm{G}$ and $a^{\mathrm{H}}=2.79 \mathrm{G}$, (b) DG from $M$. arenaria, and (c) POBN itself.

oxidation in biological tissues, amounted to $57 \pm 8 \mathrm{pmol} / \mathrm{mg} \mathrm{FW}$ in the DG.

A typical EPR spectrum of $A^{\bullet}$ was recorded in DG. The EPR spectrum showed the characteristic two lines at $g=2.005$ and $a^{\mathrm{H}}=1.8 \mathrm{G}$ (Fig. 3), in accordance with computer simulated signals obtained using the parameters mentioned above. DMSO was examined and no DMSO spin adduct was observed (Fig. 3 ). A $^{\bullet}$ content, assessed by quantification of EPR signals, was $0.04 \pm 0.01 \mathrm{pmol} / \mathrm{mg} \mathrm{FW}$. The content of $\mathrm{AH}^{-}$in DG of $M$. arenaria was $478 \pm 12 \mathrm{pmol} / \mathrm{mg} \mathrm{FW}$, and the ratio $\mathrm{A}^{\bullet} / \mathrm{AH}^{-}$was $(8 \pm 1) \times 10^{-5} \mathrm{AU}$ indicating a basal oxidative (a)

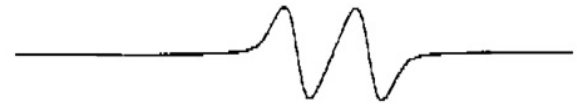

(b)

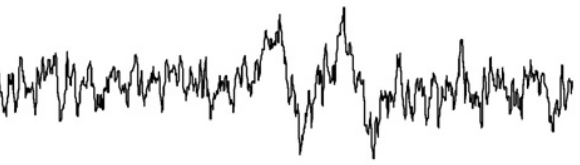

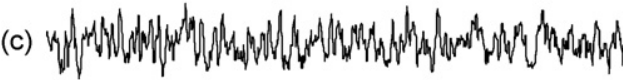

$2 \mathrm{G}$

Fig. 3. A• detection by EPR. Spectra from: (a) computer-simulated employing the following spectral parameters, $g=2.005$ and $a^{\mathrm{H}}=1.8 \mathrm{G}$, (b) DG from M. arenaria, and (c) DMSO.

stress even under non-stressed environmental conditions, depending on basal metabolic functions.

The NO content in the DG, estimated by the Griess reaction, was $613 \pm 38 \mathrm{pmol} / \mathrm{mg} \mathrm{FW}$, with non-detectable levels of nitrite. However, the estimation of NO by the nitrate and nitrite content as in this technique, could overestimate the intracellular content of NO, since both nitrate and nitrite are small and stable molecules that can diffuse freely across the membranes from the extracellular fluid. Therefore, a second method was applied and NO content in DG homogenates was assessed by EPR spin trapping measurements using the NO trap MGD-Fe at room temperature. The EPR signal is characterized by an isotropic triplet signal at $g=2.03$ and $a^{\mathrm{N}}=12.5 \mathrm{G}$, and its features are unique and enable a fingerprint-

(A) a

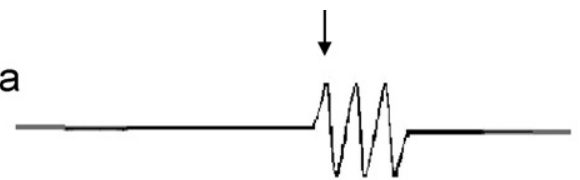

d

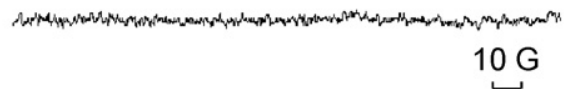

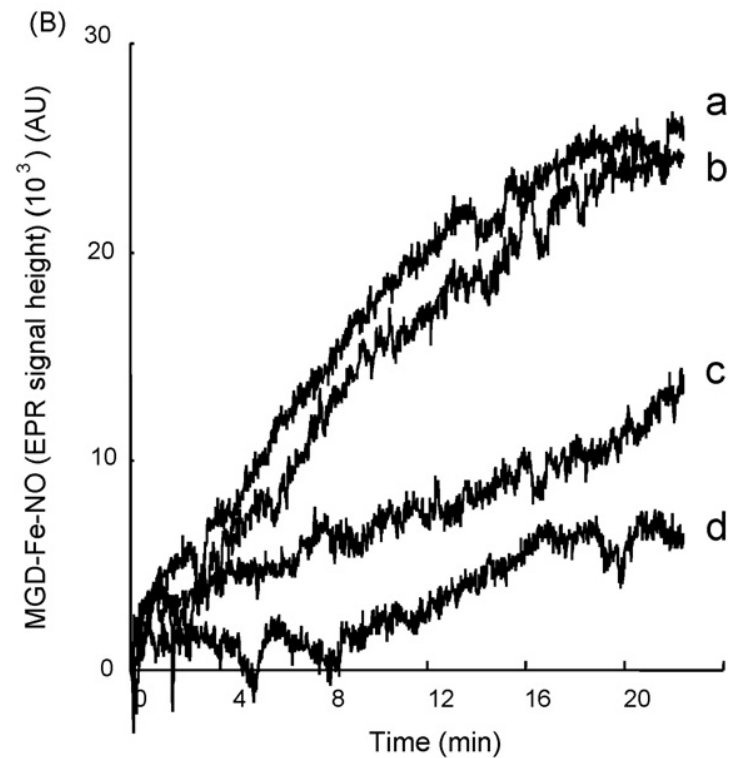

Fig. 4. (A) NO detection by EPR. Spectra from: (a) computer-simulated employing the parameters, $g=2.03$ and $a^{\mathrm{N}}=12.5 \mathrm{G}$. The arrow indicates the peak at $3411 \mathrm{G}$; (b) DG (basal NO content); (c) boiled DG; and (d) no animal tissue added. (B) Total generation rate of the MGD-Fe-NO adduct. The height of was recorded in: (a) DG incubated with $1 \mathrm{mM} \mathrm{L}-\mathrm{A}, 5 \mathrm{mM} \mathrm{MgCl}, 1 \mathrm{mM} \mathrm{CaCl} 2$ and $0.1 \mathrm{mM}$ NADPH (complete system); (b) DG incubated as in the complete system without L-A; (c) DG pre-incubated during 5 min with $5 \mathrm{mM}$ L-NAME, and incubated as in the complete system; and (d) DG pre-incubated during $5 \mathrm{~min}$ with $5 \mathrm{mM}$ L-NA, and incubated as in the complete system. 
Table 1

NO generation by NOS-like activity in DG of M. arenaria

\begin{tabular}{lc}
\hline & Rate of NOS-like activity (pmol/mg FW min) \\
\hline Complete system & $3.16 \pm 0.06$ \\
-L-A & $3.30 \pm 0.90$ \\
+5 mM L-NAME & $0.14 \pm 0.01^{*}$ \\
+5 mM L-NA & $0.11 \pm 0.09^{*}$ \\
\hline
\end{tabular}

* Significant different from the rate measured using the complete system. $P<0.05$. Fisher test.

like identification of NO (Fig. 4A). The EPR signal was neither detectable in the absence of homogenate nor in the presence of boiled homogenate (Fig. 4A). The content of NO in the DG, assessed by EPR, was $99 \pm 3 \mathrm{pmol} / \mathrm{mg}$ FW. Thus, by both methods NO was detected in the tissue under non-stressed conditions.

To further investigate the source of NO generation by DG, an assay was developed by assessing NO production by EPR in the presence of L-A and NADPH by EPR (Jasid et al., 2006). The samples were incubated up to $10 \mathrm{~min}$ in the presence of the spin trap (MGD) $)_{2}-\mathrm{Fe}^{2+}$ at $10^{\circ} \mathrm{C}$ and the required cofactors, as previously described for assaying NOS-like activity in mammals. The generation rate of NO was measured as the increase on the spectrum peak height at $3411 \mathrm{G}$ over a $20 \mathrm{~min}$ period (Fig. 4B). No NO generation was observed when the spin trap was incubated only with the cofactors. When DG were pre-incubated with known NOS-inhibitors in the presence of all the required cofactors for NOS-like activity, the rate of NO generation was significantly inhibited (Fig. 4B) as compared to the complete system. Controls without addition of L-A were performed and non-significant differences were obtained in the rate of NO generation as compared to the complete system (Fig. 4B). This lack of effect of L-A supplementation could be attributed either to a non-limiting endogenous supply of $\mathrm{L}-\mathrm{A}$, as described in plant tissues (Jasid et al., 2006), or to the increase in L-A content by the cleavage of proteins due to the activity of proteases during sample preparation. Following boiling of the samples, the initial rate of generation of NO (calculated as the rate up to $10 \mathrm{~min}$ ) diminished to $2.2 \mathrm{pmol} /(\mathrm{min} \mathrm{mgFW})$, suggesting that the pre-boiling signal represented the addition of both enzymatic and non-enzymatic activities. Thus, enzymatic activity, shown in Table 1, was assessed subtracting the rate of generation of NO of the boiled sample from the rate recorded in the complete system. The enzymatic generation rate of $\mathrm{NO}$ was inhibited by $96 \%$ after pre-incubation with L-NAME, and by $97 \%$ after pre-incubation with L-NA (Table 1 ).

\section{Discussion}

One objective of this work was to analyze oxidative metabolism in $M$. arenaria for interspecific comparisons. $\mathrm{Fe}$ is an essential micronutrient, also in bivalves, and permanently required for synthesis of $\mathrm{Fe}$-containing proteins. It is taken up from the environment (Dick et al., 2007) and presumably excreted with faeces and incorporated in the calcareous shells. A permanent Fe flux exists from the environment to the shell, via gills, DG and mantle tissues. In marine invertebrates Fe content strongly depends on the characteristics of the natural environment. Laternula elliptica is an Antarctic mollusc ecologically similar to the species $M$. arenaria from the North Sea intertidal areas (Puntarulo et al., 2004); however, the vulcanic nature of the rocks containing Fe in King George Island, Antarctic, may be a source for Fe in Potter Cove sediments, and by contrast in the Wadden Sea riverine inputs come from salt marches that are not so enrich in Fe. Recently data reported by Malanga et al. (2008) showed that total Fe content in L. elliptica was $5 \pm 1,4 \pm 1$ and $1.2 \pm 0.4 \mathrm{nmol} / \mathrm{mg} \mathrm{FW}$ in DG, gills and mantle, respectively. Thus, Fe content in the tissues of the molluscs would dependent on exogenous Fe availability since the exposure to sediments in the Wadden Sea, with a content of Fe that represents the $31 \%$ of the value in Potter Cove, leads to a significantly lower Fe content in $M$. arenaria in the three tissues. Data in Table 2 shows the Fe content in DG of several molluscs in relation to Fe content in the natural environment.

Elimination of Fe could be a strategy to minimize the hazardous effects of this potentially toxic Fenton reactant. The concentration of total Fe in mantle represents 35\% of the value in DG of $M$. arenaria suggesting that Fe is ingested via the food and then transferred to the mantle tissue to be sequestered into the shell. Previous data from Mercenaria mercenaria (Thorn et al., 1995) reported that most elements were more concentrated on the exterior surfaces of the shell than they were within the main shell, however, Fe concentrations peak were located near the surface $(30 \mu \mathrm{m})$ and farther in $(180 \mu \mathrm{m})$. This second peak of Fe content is probably due to Fe incorporation from the DG. Dick et al. (2007) investigated the Fe signal in different age rings of the Antarctic soft shell clam L. elliptica with laser ablation techniques and found highest incorporation in early age rings of young animals. This might simply reflect higher specific metabolism and filtration rates, or a more efficient transfer of Fe to the shell in young specimens. Similar age-dependent shell profiles of Fe deposition have been recorded in M. arenaria (Dick and Abele, unpublished results), and could be a common phenomenon in bivalve development.

The $\mathrm{A}^{\bullet} / \mathrm{AH}^{-}$ratio reflects the actual state of one part of the oxidative defense system mainly at the hydrophilic level and provides an early and simple diagnosis of stress (Kozak et al., 1997; Estévez et al., 2001; Galleano et al., 2002). The reductant $\mathrm{AH}^{-}$, which is mostly present in the cellular cytosol, not only participates in the release of Fe from Ft (Laulhère et al., 1996), but also rapidly undergoes Fe catalyzed auto-oxidation (Graziano and Lamattina, 2005). In the absence of transition metals, the auto-oxidation of biomolecules, such as proteins, lipids and DNA, is a negligible process (Miller et al., 1990) and auto-oxidation reactions could be disregarded. A $^{\bullet}$ generation rate, as described by the following reaction:

$\mathrm{AH}^{-}+\mathrm{Fe}^{3+} \stackrel{k_{1}}{\longrightarrow} \mathrm{A} \cdot+\mathrm{Fe}^{2+}$

has an estimated value for the rate constant $\left(k_{1}\right)$ in Eq. (3), of $30 \mathrm{M}^{-1} \mathrm{~s}^{-1}$ (Galleano et al., 2002) under standard conditions. Thus, Fe content strongly affects the cellular content of $A^{\bullet}$ :

$\frac{\mathrm{d}\left[\mathrm{A}^{\bullet}\right]}{\mathrm{d} t}=k_{1}\left[\mathrm{Fe}^{3+}\right]\left[\mathrm{AH}^{-}\right]$

Table 2

Fe content in DG of molluscs and their natural environments

\begin{tabular}{|c|c|c|c|c|c|}
\hline Mollusc & $\begin{array}{l}\text { Fe content DG } \\
(\mathrm{nmol} / \mathrm{mg} \mathrm{FW})\end{array}$ & Reference & Environment & Enviromental Fe content & Reference \\
\hline Nacella concinna (subtidal) & $3 \pm 2$ & Malanga et al. (2008) & Potter Cove, Antarctic & 18.4-22.6 nM (near bottom water) & Puntarulo et al. (2004) \\
\hline N. concinna (intertidal) & $1.8 \pm 0.5$ & Malanga et al. (2008) & Potter Cove, Antarctic & $8.8-12.6 \mathrm{nM}$ (near surface water) & Puntarulo et al. (2004) \\
\hline L. elliptica & $5 \pm 1$ & Estévez et al. (2002) & Potter Cove, Antarctic & $24.2 \mathrm{mgFe} / \mathrm{g} \mathrm{DW}$ (sediment) & Puntarulo et al. (2004) \\
\hline M. arenaria & $1.1 \pm 0.2$ & Puntarulo et al. (2004) & Dorum Waden Sea & $7.5 \pm 0.6 \mathrm{mgFe} / \mathrm{g} \mathrm{DW} \mathrm{D}^{\mathrm{a}}$ (sediment) & Estévez et al. (2002) \\
\hline
\end{tabular}

a Dry weight. 
On the other hand, $\mathrm{Fe}^{2+}$ catalyzes lipid radical generation according to the following reaction:

Lipid $\underset{\mathrm{H}^{+}}{\stackrel{\mathrm{Fe}^{2+}}{\longrightarrow}}$ Lipid radical (LR•)

Detectable amounts of both, $\mathrm{A}^{\bullet}$ and lipid radicals, are generated in $M$. arenaria even under non-stressed conditions. Previous observations from our laboratory indicate a correlation between lipid peroxidation rates and Fe content in DG material of the mud clams L. elliptica and M. arenaria (Estévez et al., 2002). However, not total Fe but the Fe in the LIP is responsible for catalyzing the above radical reactions. Assessing the LIP by two independent techniques, we confirmed that even under non-stressed conditions a fraction of total Fe in the bivalve DG is labile. It is accepted that the affinity of a chelator for Fe, its ability to permeate different cell compartments as well as the steric accessibility of specific metal binding sites on proteins could all influence the LIP, which intracellular concentration needs to be tightly controlled.

Regarding the content of nitrogen reactive species in M. arenaria, the results presented here employing EPR spectroscopy, are the first evidence that support the hypothesis that $\mathrm{NO}$ is being generated in this animal. The total generation rate of NO can originate not only from the activity of a NOS-like enzyme but other sources should be operative. In this work, the pathway dependent on the activity of NOS-like enzyme employing L-A and NADPH was identified. Other alternative sources, such as NO release from endogenous nitrosoglutathionyl complexes (GSNO) or similar compounds could be relevant under certain physiological or pathological conditions. The rate of the reaction of NO with superoxide anion $\left(\mathrm{O}_{2}{ }^{-}\right)$to generate peroxynitrite $\left(\mathrm{ONOO}^{-}\right)$seems to be the main pathway for the disappearance of $\mathrm{NO}$, even though other cellular compounds, such as glutathione (GSH), could participate in NO metabolism through quenching reactions. In a first approach, it could be assumed from the value of the kinetic constant for $\mathrm{NO}$ reaction with $\mathrm{O}_{2}{ }^{-}$ $\left(k=6.7 \times 10^{9} \mathrm{M} \mathrm{s}^{-1}\right.$, Huie and Padmaja, 1993), that $\mathrm{ONOO}^{-}$generation is the main pathway leading to NO disappearance. Further studies are required to analyze the effect of environmental stress conditions on NO steady state concentration, and the role of the cellular generation of $\mathrm{ONOO}^{-}$in terms of nitrosative-dependent damage. The data presented here document the presence of highly reactive species, including nitrogen active radical species, in $M$. arenaria.

\section{Acknowledgements}

This study was supported by grants from the University of Buenos Aires (B017), Agencia Nacional de Promoción Científica y Tecnológica (ANPCyT) (PICT 11187), CONICET (PIP 5706) and DAAD fellowship for P.M.G. S.P. is career investigator from CONICET and P.M.G. is a fellow from the University of Buenos Aires.

\section{References}

Abele, D., Puntarulo, S., 2004. Formation of reactive species and induction of antioxidant defence systems in polar and temperate marine invertebrates and fish. Comp. Biochem. Physiol. A 138, 405-415.

Abele, D., Heise, K., Pörtner, H.O., Puntarulo, S., 2002. Temperature-dependence of mitochondrial function and production of reactive oxygen species in the intertidal mud clam Mya arenaria. J. Exp. Biol. 205, 1831-1841.

Brumby, P.E., Massey, V., 1967. Determination of nonheme iron, total iron, and copper. Meth. Enzymol. 10, 463-472.

Buettner, G.R., 1987. Spin trapping: ESR parameters of spin adducts. Free Radic. Biol. Med. 3 (4), 259-303.

Darbari, D., Loyevsky, M., Gordeuk, V., Kark, J.A., Castro, O., Rana, S., Apprey, V., Kurantsin-Mills, J., 2003. Fluorescence measurements of the labile iron pool of sickle erythrocytes. Blood 102, 357-364.

Dick, D., Philipp, E., Kriews, M., Abele, D., 2007. Is the umbo matrix of bivalve shells (Laternula elliptica) a climate archive? Aquat. Toxicol. 84, 450-456.
Espósito, B.P., Epsztein, S., Breuer, W., Cabantchik, Z.I., 2002. A review of fluorescente methods for assessing labile iron in cells and biological fluids. Anal. Biochem. 304, 1-18.

Estévez, M.S., Malanga, G., Puntarulo, S., 2001. Iron-dependent oxidative stress in Chlorella vulgaris. Plant Sci. 161, 9-17.

Estévez, M.S., Abele, D., Puntarulo, S., 2002. Lipid radical generation in polar (Laternula elliptica) and temperate (Mya arenaria) bivalves. Comp. Biochem. Physiol. B 132, 729-737.

Galleano, M., Aimo, L., Puntarulo, S., 2002. Ascorbyl radical/ascorbate ratio in plasma from iron overloaded rats as oxidative stress indicator. Toxicol. Lett. 133, 193-201.

Graziano, M., Lamattina, L., 2005. Nitric oxide and iron in plants: an emerging and converging story. Trends Plant Sci. 10 (1), 4-8

Huie, R.E., Padmaja, S., 1993. The reaction of NO with superoxide. Free Radic. Res. Commun. 18 (4), 195-199.

Imamura, M., Yang, J., Yamakawa, M., 2002. cDNA cloning, chracterization and gene expression of nitric oxide synthase from the silkworm, Bombyx mori. Insect Mol. Biol. 11 (3), 257-265.

Jacklet, J.W., 1997. Nitric oxide signaling in invertebrates. Invertebr. Neurosci. 3, 1-14.

Jasid, S., Simontacchi, M., Bartoli, C.G., Puntarulo, S., 2006. Chloroplasts as a nitric oxide cellular source. Effect of reactive nitrogen species on chloroplastic lipids and proteins. Plant Physiol. 142, 1246-1255.

Johansson, K.U.I., Carlberg, M., 1995. NO-synthase: what can research on invertebrates add to what is already known? Adv. Neuroimmunol. 5, 431-442.

Jurkiewicz, B.A., Buettner, G.R., 1994. Ultraviolet light-induced free radical formation in skin: an electron paramagnetic resonance study. Photochem. Photobiol. 59, $1-4$.

Kakhlon, O., Cabantchik, Z.I., 2002. The labile iron pool: characterization, measurement, and participation in cellular processes. Free Radic. Biol. Med. 33, 1037-1046.

Knowles, R.G., 1997. Nitric oxide biochemistry. Biochem. Soc. Trans. 25 (3), 895-901.

Knowles, R.G., Moncada, S., 1994. Nitric oxide synthases in mammals. Biochem. J. 298, 249-258.

Kölsch, S., Gebhardt, S., Terjung, F., Liebezeit, G., Reuter, R., Rullkötter, J., Brumsack, H.J., 2003. Freshwater discharge into the East Frisian Wadden Sea: geochemistry of humic matter-rich waters. Berichte-Forschungszentrum Terramare, 12 (Ext. Abs. 71).

Kotake, Y., Tanigawa, T., Tanigawa, M., Ueno, I., Randel Allen, D., Lai, C.-S., 1996. Continuous monitoring of cellular nitric oxide generation by spin trapping with an iron-dithiocarbamate complex. Biochim. Biophys. Acta 1289, 362-368.

Kozak, R.G., Malanga, G., Caro, A., Puntarulo, S., 1997. Ascorbate free radical content in photosynthetic organisms alter exposure to ultraviolet-B. Rec. Res. Dev. Plant Physiol. 1, 233-239.

Kruszewski, M., 2003. Labile iron pool: the main determinant of cellular response to oxidative stress. Mutat. Res. 531 (1-2), 81-92.

Kruszewski, M., 2004. The role of labile iron pool in cardiovascular diseases. Acta Biochim. Pol. 51 (2), 471-480.

Kutnink, M.A., Hawkes, W.C., Schaus, E.E., Omaye, S.T., 1987. An internal standard method for the unattended high-performance liquid chromatographic analysis of ascorbic acid in blood components. Anal. Biochem. 166, 424-430.

Laulhère, J.P., Barcelò, F., Fontecave, M., 1996. Dynamic equilibria in iron uptake and release by ferritin. Biometals 9 (3), 303-309.

Lesser, M.P., 2006. Oxidative stress in marine environments: biochemistry and physiological ecology. Annu. Rev. Physiol. 68, 253-278.

Livingstone, D.R., 1991. Organic xenobiotic metabolism in marine invertebrates. Adv. Comp. Environ. Physiol. 7, 45-185.

Livingstone, D.R., García Martínez, P., Michel, X., Narbonne, J.F., O’Hara, S., Ribera, D., Winston, G.W., 1990. Oxyradical production as a pollution-mediated mechanism of toxicity in the common mussel, Mytilus edulis L., and other molluscs. Funct. Ecol. 3, 415-424

Luckhart, S., Vodovotz, Y., Cui, L., Rosenberg, R., 1998. The mosquito Anopheles stephensi limits malaria parasite development with inducible synthesis of nitric oxide. Proc. Natl. Acad. Sci. U.S.A. 95 (10), 5700-5705.

Malanga, G., González, P.M., Estévez, M.S., Abele, D., Puntarulo S., 2008. Oxidative stress in Antarctic algae and mollusks. In: Wiencke, C., Ferreyra, G.A., Abele, D., Marenssi, S. (Eds.), Reports on Polar and Marine Research: the Antarctic ecosystem of Potter Cove, King-George Island (Isla 25 de Mayo). Synopsis of research performed 1999-2006 at the Dallmann Laboratory and Jubany Station, pp. 208-215.

Miller, D.M., Buettner, G.R., Aust, S.D., 1990. Transition metals as catalysts of "autooxidation" reactions. Free Radic. Biol. Med. 8, 95-108.

Moncada, S., Higgs, E.A., 1995. Molecular mechanisms and therapeutic strategies related to nitric oxide. FASEB J. 9, 1319-1330.

Moncada, S., Palmer, R.M.J., Higgs, E.A., 1991. Nitric oxide: physiology, pathophysiology and pharmacology. Pharmacol. Rev. 43, 109-142.

Moroz, L.L., Gillette, R., 1995. From Polyplacophora to Cephalopoda: comparative analysis of nitric oxide signalling in mollusca. Acta Biol. Hung. 46 (2-4), 169-182.

Nighorn, A., Gibson, N.J., Rivers, D.M., Hildebrand, J.G., Morton, D.B., 1998. The nitric oxide-cGMP pathway may mediate communication between sensory afferents and projection neurons in the antennal lobe of Manduca sexta. J. Neurosci. 18 (18), 7244-7255.

Petrák, J.V., Vyoral, D., 2001. Detection of iron-containing proteins contributing to the cellular labile iron pool by a native electrophoresis metal blotting technique. J. Inorg. Biochem. 86 (4), 669-675. 
Petrat, F., De Groot, H. Sustmann, R., Rauen, U., 2002. The chelatable iron pool in living cells: a methodically defined quantity. Biol. Chem. 383 , 489-502.

Puntarulo, S., Cederbaum, A.I., 1988. Comparison of the ability of the ferric complexes to catalyze microsomal chemiluminescence, lipid peroxidation and hydroxyl radical generation. Arch. Biochem. Biophys. 264, 482-491.

Puntarulo, S., Boveris, A.D., Estévez, M.S., 2004. Oxidative stress and iron in molluscs adapted to different environments. In: Puntarulo, S., Boveris, A. (Eds.), Proceedings of the XII Biennial Meeting of the Society for Free Radical Research Society. Medimond srl, Bologna, Italy, pp. 377-382.

Regulski, M., Tully, T. 1995. Molecular and biochemical characterization of dNOS: Drosophila Ca2+/calmodulin-dependent nitric oxide synthase. Proc. Natl. Acad. Sci. U.S.A. 92 (20), 9072-9076.

Robello, E., Galatro, A., Puntarulo, S., 2007. Iron role in oxidative metabolism of soybean axes upon growth effect of iron overload. Plant Sci. 172, 939-947.

Schneppensieper, T., Finkler, S., Czap, A., van Eldik, R., Heus, M., Nieuwenhuizen, P., Wreesmann, C., Abma, W., 2001. Tuning the reversible binding of NO to iron(II) aminocarboxylate and related complexes in aqueous solution. Eur. J. Inorg. Chem. 2, 491-501.

Stefano, G.B., Ottaviani, E., 2002. The biochemical substrate of nitric oxide signaling is present in primitive non-cognitive organisms. Brain Res. 924, 82-89.
Storch, D., Abele, D., Pörtner, H.O.,2001. The effect of hydrogen peroxide on isolated body wall of the lugworm Arenicola marina at different extracellular $\mathrm{pH}$ levels. Comp. Biochem. Physiol. C 128, 391-399.

Tafalla, C., Gómez-León, J., Novoa, B., Figueras, A., 2003. Nitric oxide production by carpet shell clam (Ruditapes decussatus) hemocytes. Dev. Comp. Immunol. 27, 197-205.

Tarpey, M.M., Wink, D.A., Grisham, M.B., 2004. Methods for detection of reactive metabolites of oxygen and nitrogen: in vitro and in vivo considerations. Am. J. Physiol. Regul. Integr. Comp. Physiol. 286, R431-R444.

Thorn, K., Cerrato, R.M., Rivers, M.L., 1995. Elemental distributions in marine bivalve shells as measured by synchrotron X-ray fluorescence. Biol. Bull. 188, 5767.

Uchiyama, M., Mihara, M., 1978. Determination of malonaldehyde precursor in tissues by thiobarbituric acid test. Anal. Biochem. 86, 271-278.

Verdon, C.P., Burton, B.A., Prior, R.L., 1995. Sample pretreatment with nitrate reductase and glucose-6-phosphate dehydrogenase quantitatively reduces nitrate while avoiding interference by $\mathrm{NADP}^{+}$when the Griess reaction is used to assay for nitrite. Anal. Biochem. 224 (2), 502-508.

Winston, G.W., Di Giulio, R.T., 1991. Pro-oxidant and antioxidant mechanisms in aquatic organisms. Aquat. Toxicol. 19, 137-167.

Woodmansee, A.N., Imlay, J.A., 2002. Quantitation of intracellular free iron by electron paramagnetic resonance spectroscopy. Methods Enzymol. 349, 3-9. 